\title{
STRATEGI PENGEMBANGAN AGROINDUSTRI BERBAHAN BAKU BUAH SEGAR (STUDI KASUS SOP BUAH ICA DI MANADO)
}

\author{
Yosiko H. Panambunan \\ Agnes E. Loho \\ Eyverson Ruauw
}

\begin{abstract}
This study aims to identify the external factors and internal factors that can affect the agroindustry "Sop Buah Ica", and formulate strategies in the development of agro-industry Sop Buah Ica in the study area.The research was done on location "Sop Buah Ica" in Manado Boulevard, during the three months from May 2015 through July 2015. The data obtained are primary and secondary data. Primary data sourced from opinions and interviews with relevant parties, among others, business owners, customer and employees who are the subject of research. Secondary data is data obtained by researchers who comes from a document from the relevant authorities, such as Internet and library resources or literature books. Data were analyzed using SWOT analysis.Based on the results of SWOT analysis diagram; Sop Buah ICA business is located in quadrant I, which is an aggressive strategy. In this position, a situation which is very beneficial for business Sop Buah has a bright prospect in the future because it has the power and the enormous opportunities that should be utilized. So that needs to be done some of strategies that need to be done, which is to harness capital is always available with the purchase of business purposes in fruit soup, take advantage of market opportunities with the selling price, Fruit Sop product promotion in public places to add new customers, take advantage of other fruits that are on the market, for the purposes of processing Sop Buah, it can also be helpful as it gives a new color to the contents of the fruit Sop, look for other suppliers.
\end{abstract}

Keyword: Fruits soup, fresh fruit, agro-industry development, Manado

\begin{abstract}
ABSTRAK
Penelitian ini bertujuan untuk mengidentifikasi faktor eksternal dan faktor internal yang dapat mempengaruhi agroindustri Sop Buah Ica, dan merumuskan strategi-strategi dalam pengembangan agroindustri sop buah ica di daerah penelitian. Penelitian ini dilakukan di lokasi Usaha Sop Buah Ica di Boulevard Manado, selama 3 bulan dari bulan mei 2015 sampai juli 2015. Data yang diperoleh adalah data primer dan sekunder. Data primer yaitu data yang bersumber dari pendapat dan wawancara dengan pihak-pihak yang terkait antara lain, pemilik usaha, konsumen dan karyawan yang menjadi subjek penelitian. Data sekunder yaitu data yang diperoleh oleh peneliti yang bersumber dari dokumen dari instansi terkait, seperti: internet dan sumber pustaka atau buku literatur. Data di anilisis dengan menggunakan Analisis SWOT. Berdasarkan hasil dari analisis diagram SWOT, usaha sop buah ICA ini berada pada kuadran I yaitu strategi agresif. Pada posisi ini merupakan situasi yang sangat menguntungkan karena usaha Sop Buah ini memiliki prospek yang cerah kedepan karena memiliki kekuatan dan peluang yang sangat besar yang harus dimanfaatkan. Sehingga perlu dilakukan beberapa strategi strategi yang perlu dilakukan, yaitu memanfaatkan modal yang selalu tersedia dengan membeli keperluan dalam usaha sop buah, memanfaatkan peluang pasar dengan harga jual produk, melakukan promosi produk Sop Buah ke tempat umum untuk menambah konsumen baru, meningkatkan sumber daya manusia SDM, memanfaatkan buah-buahan lain yang ada di pasar, untuk keperluan pengolahan Sop Buah, itu juga bisa membantu karena memberikan warna baru terhadap isi Sop buah, mencari pemasok lain selain pemasok yang sudah menjadi langganan.
\end{abstract}

Kata kunci: Sop Buah, buah segar, pengembangan agroindustri, Manado 


\section{PENDAHULUAN}

\section{Latar Belakang}

Ketatnya kompetisi dalam dunia industri dewasa ini sebagai akibat dari perkembangan teknologi menuntut setiap perusahaan untuk lebih teliti dan terarah dalam menilai dan memfokuskan diri dalam persaingan produk maupun sistem industri. Penilaian sebuah perusahaan terhadap produknya dan sistemnya sendiri dan terhadap produk dan sistem dari para pesaingnya membuat perusahaan mengetahui yang harus dilakukannya untuk menghadapi para pesaingnya. Sedangkan fokus produk dan sistem sebuah perusahaan akan menentukan masa depan dari usaha tersebut.

Industri pengolahan buah-buahan merupakan salah satu bisnis industri yang memiliki peluang pasar yang besar dan sangat potensial. Pengolahan produk pertaninan membutuhkan pengolahan dan penanganan yang tepat karena menginggat sifat produk pertanian yang musiman dan mudah rusak, agar produk buah-buahan dapat memanfaatkan peluang menembus pasar serta mengembangkannya. Pengembangan buahbuahan berpola agribisnis dan agroindustri sangat cerah karena adanya peluang industri pangan olahan di dalam negeri yang berkembang pesat dan cukup menjanjikan. Manfaat buah-buahan untuk kesehatan sangat beragam, berupa menghindarkan dari berbagai penyakit. Beberapa artikel mengenai Manfaat buah memang telah banyak dibahas, namun sebenarnya manfaat ini dapat beragam tergantung dari buah dan jenisnya. Oleh karena itu dengan mengkonsumsi buah maka kita akan mendapatkan kecukupan gizi. Selain itu, diikuti dengan kesadaran masyarakat akan kesehatan semakin meningkat seiring dengan kemajuan teknologi informasi di bidang pangan. Hal ini sejalan dengan laju pertumbuhan penduduk dan semakin banyaknya masyarakat yang menyadari pentingnya kecukupan gizi yang berasal dari buah-buahan (Dinas Pertanian Kota Depok, 2007:1).

Kota manado adalah ibu kota dari Provinsi Sulawesi Utara, yang dikenal dengan cuaca panas. Oleh karena itu mengkonsumsi makanan segar seperti buah-buahan termasuk jenis buahan yang telah diolah, contohnya produk sop sangat tepat untuk menghilangkan dehaga dan digemari oleh masyarakat manado. Salah satu usaha pengolahan buah buahan segar adalah Usaha Sop Buah Ica. Usaha sop buah ica merupakan usaha yang berkategori pengolahan hasil buah buahan segar dimana bahan dasar utamanya dari produk pertanian. Usaha sop buah yang terletak di jalan Tendean Boulevard Manado yang menjual banyak macam produk makanan dengan sop buah sebagai jajanan utamanya. Sop Buah merupakan salah satu produk olahan dari pertanian di mana hasil buah-buahan dari petani diolah menjadi minuman yang dingin dan enak untuk dinikmati disaat siang hari dengan cuaca yang panas, ini juga bagus untuk kesehatan karena berisi buah yang kaya vitamin. Sop buah merupakan andalan dari produk produk yang dijual di tempat usaha ibu hanna. Sop buah memiliki beberapa jenis rasa diantaranya, sop buah alpukat, sop buah sirsak, sop buah manga, sop buah durian, durian tok, alpukat durian, sop buah anggur, sop buah strawberry, sop buah apel, sop buah melon, sop buah nangka, dan sop buah semangka. Dari beberapa jenis sop buah yang di tawarkan di atas sop buah alpukat yang paling banyak disukai dan menjadi buruan para konsumen. Keberadaan usaha ini dapat menyerap tenaga kerja, meningkatkan keterampilan produsen dalam mengolah hasil usahatani, dan juga sebagai penggerak industry lain bisa menghasilkan produk olahan dari pertanian sehingga menambah nilai tambah bagi petani. Dapat kita ketahui bahan baku yang digunakan dalam usaha ini adalah dari produk pertanian yaitu buah buahan, kita ketahui sifat produk pertanian yang mudah rusak sehingga di perlukan pengemasan teknologi dan sarana transpotarsi dan juga sebagian besar dari produk pertanian bersifat musiman sehingga sehingga dibutuhkan penangganan serius dalam menanggapi hal tersebut.

Sejak mulai beroperasi pada Tahun 2012 sampai saat ini Sop Buah Ica terus mengalami perkembangan, Awalnya sop buah ica berlokasi di halaman Gereja Internasional Christian Assembly (ICA) dari lokasi inilah dipilihnya nama Sop Buah ICA, dan dalam perkembangnya saat ini Sop Buah Ica banyak kali berpindah tempat dan pada saat ini mendapat tempat di kawasan Lion Mall'Boulevard Manado. Berdasarkan gambaran diatas sangat penting di lakukan strategi apa yang digunakan dalam usaha Sop Buah Ica, dan ada 
juga faktor-faktor yang berpengaruh baik faktor internal maupun eksternal secara positif maupun negatif. untuk itu perlu sebelum merumuskan strategi perkembangannya, perlu diketahui terlebih dahulu faktor-faktor mana yang berpengaruh terhadap pengembangan sop buah ica. Itulah sebabnya peneliti melakukan penelitian yang berjudul Strategi Pengembangan Agroindustri berbahan baku buah (Studi Kasus Sop Buah Ica di Boulevard Manado).

\section{Perumusan masalah}

Berdasarkan latar belakang yang ada, maka yang menjadi perumusan masalah yaitu:

1. Faktor apa yang menjadi kekuatan, kelemahan, peluang dan ancaman dalam pengembangan Sop Buah ICA.

2. Bagaimana strategi dalam mengembangkan agroindustri sop buah ica?

\section{Tujuan penelitian}

Berdasarkan rumusan masalah, adapun tujuan penelitian ini adalah sebagai berikut:

1. Menentukan faktor eksternal dan faktor internal yang dapat mempengaruhi agroindustri Sop Buah Ica.

2. Merumuskan strategi-strategi dalam pengembangan agroindustri sop buah ica di daerah penelitian.

\section{Manfaat penelitian}

Manfaat sebagai sumber menambah wawasan dan menambah ilmu pengetahuan bagi peneliti, dan sebagai bahan referensi bagi mahasiswa lain yang melakukan penelitian yang sama.

\section{METODELOGI PENELITIAN}

\section{Waktu dan Tempat Penelitian}

Penelitian ini dilaksanakan selama tiga bulan dari Bulan Mei sampai Juli 2015 di Sop Buah Ica Boulevard Manado, mulai dari persiapan sampai ujian sarjana.

\section{Metode Pengumpulan Data}

Metode yang digunakan dalam peneliti ini adalah studi kasus dengan menentukan Faktor Internal dan Faktor Eksternal yang berpengaruh pada usaha Sop Buah Ica. Teknik yang digunakan untuk memperoleh data adalah dengan wawancara secara langsung dengan pihak yang terkait. Responden yang di pilih adalah dari pemilik, 9 orang karyawan yang bekerja, dan 30 responden dari konsumen.

\section{Jenis dan Sumber Data}

Jenis data yang digunakan dalam penelitian ini adalah data primer dan data sekunder:

a) Data primer yaitu data yang bersumber dari opini dan wawancara dengan pihak-pihak yang terkait, antara lain pemilik usaha, komsumen dan karyawan yang menjadi subjek penelitian.

b) Data sekunder yaitu data yang diperoleh oleh peneliti yang bersumber dari dokumen dari instansi terkait, seperti: internet dan sumber pustaka atau buku literatur.

\section{Konsep Pengukuran Variabel}

Variabel yang diukur dalam penilitian ini adalah faktor internal berupa manajemen, pemasaran, Sumber Daya Manusia (SDM), produksi dan operasi, kompetensi inti, pelayanan, lokasi, kualitas produk dan tentang keuangan. Faktor eksternal berupa kebijakan pemerintah dan politik, teknologi, pesaing, ancaman dari pendatang baru, kekuatan tawar-menawar konsumen, kekuatan tawar-menawar pemasok, dan ancaman dari produk pengganti atau produk substitusi.

\section{Metode Analisis Data}

Metode analisis data yang digunakan dalam penelitian ini adalah metode secara deskriptif dengan menggunakan analisis SWOT.

SWOT merupakan sebuah metode perencanaan strategis yang digunakan untuk mengevaluasi Kekuatan, Kelemahan, Peluang dan Ancaman dalam suatu proyek atau suatu spekulasi bisnis Suryatama (2014). Proses ini melibatkan penentuan tujuan yang spesifik dari spekulasi bisnis atau proyek dan mengidentifikasi faktor internal dan faktor eksernal yang mendukung dan yang tidak dalam mencapai tujuan tersebut.

\section{A. Matriks Analisis IFAS dan Matriks Analisis EFAS}

Matriks IFAS digunakan untuk mengidentifikasi faktor-faktor internal, dimaksudkan untuk mengembangkan daftar kekuatan yang dapat dimanfaatkan dan daftar kelemahan yang harus diatasi, kemudian dilakukan dengan pembobotan atau peratingan Rangkuti (2006). Adapun cara penentuan strategi internal IFAS adalah sebagai berikut: 
1) Menentukan faktor-faktor yang menjadi kekuatan serta kelamahan perusahaan dalam kolom 1.

2) Memberikan bobot masing masing faktor dalam kolom 2, tersebut dengan sekala mulai dari 1,0 (paling penting) sampai 0,0 (tidak penting), berdasarkan pengaruh faktor-faktor tersebut terhadap posisi strategi perusahaan (semua bobot tersebut jumlahnya tidak boleh melebihi skor total 1,00)

3) Menghitung rating (dalam kolom 3) untuk masing masing faktor dengan memberikan skala mulai dari 4 (outstanding) sampai dengan 1 (poor) berdasarkan pengaruh faktor tersebut terhadap kondisi perusahaan yang bersangkutan. Variabel yang bersifat postif (semua variabel yang masuk kategori kekuatan), diberi nilai dari +1 sampai dengan +4 (sangat baik). Sedangkan variabel yang bersifat negative, kebalikannya. Jika kelamahan besar skali nilainya adalah 1 , sedangkan kelamahannya kecil nilainya adalah 4 .

4) Megalihkan bobot pada kolom 2 dengan rating pada kolom 3, untuk memperoleh faktor pembobotan dalam kolo 4. Hasilnya berupa skor pembobotan untuk masingmasing faktor yang nilainya bervariasi mulai dari 4,0(outstanding) sampai dengan 1(poor).

5) Menjumlahkan skor pembobotan (pada kolom 4), untuk memperoleh jumlah total skor pembobotan. Nilai total ini menunjukan bagaimana perusahaan tertentu bereaksi terhadap faktor-faktor strategis internalnya.

Tabel 1. Internal Faktor Strategi (IFAS)

\begin{tabular}{|c|c|c|c|}
\hline $\begin{array}{c}\text { Faktor-Faktor } \\
\text { Strategi Internal }\end{array}$ & Bobot & Rating & $\begin{array}{c}\text { Skor }= \\
\text { Bobot } x \\
\text { Rating }\end{array}$ \\
\hline $\begin{array}{ll}\text { a) } & \text { Kekuata } \\
& \mathrm{n} / \text { Streng } \\
& h t(S)\end{array}$ & & & \\
\hline $\begin{array}{ll}1 . & \ldots \ldots \\
2 . & \ldots \ldots\end{array}$ & & & \\
\hline Jumlah (A) & $\mathbf{A}$ & & $\mathbf{A}$ \\
\hline b) $\begin{array}{l}\text { Kelemah } \\
\text { an/Weak } \\
\text { ness }(W)\end{array}$ & & & \\
\hline $\begin{array}{ll}1 . & \ldots \\
2 . & \ldots \ldots \\
\end{array}$ & & & \\
\hline Jumlah (B) & B & & \\
\hline Total & $\begin{array}{c}(A+B= \\
1)\end{array}$ & & $(A+B)$ \\
\hline
\end{tabular}

Tujuan dari analisis eksternal adalah untuk mengembangkan suatu daftar peluang yang dapat dimanfaatkan dan daftar ancaman yang harus dihindari. Sedangkan, cara menentukan faktor strategi eksternal (EFAS) menurut Rangkuti (2006) adalah sebagai berikut:

1) Memasukan data atau informasi dalam kolom 1, faktor yang menjadi peluang dan ancaman usaha.

2) Memberikan bobot masing masing faktor dalam kolom 2, tersebut dengan sekala mulai dari 1,0 (paling penting) sampai 0,0 (tidak penting), faktor faktor tersebut kemungkinan dapat memberikan dampak terhadap faktor strategis.

3) Hitung rating (dalam kolom 3) untuk masing masing faktor dengan memberikan skala mulai dari 4 (outstanding) sampai dengan 1 (poor) berdasarkan pengaruh faktor tersebut terhadap kondisi perusahaan yang bersangkutan. Pemberian nilai rating untuk faktor peluang bersifat positif (peluang yang semakin besar diberi rating +4 , tetapi jika peluang kecil, diberi rating +1 ). Pemberian nilai rating ancaman adalah kebalikannya. Misalnya, jika nilai ancamanya sangat besar, ratingnya adalah 1. Sebaliknya jika nilai ancamannya sedikit diberi ratingnya 4.

Kalikan bobot pada kolom 2 dengan rating pada kolom 3, untuk memperoleh faktor pembobotan dalam kolom 4. Hasilnya berupa skor pembobotan untuk masing masing faktor yang nilainya bervariasi mulai dari 4,0(outstanding) sampai dengan 1,0 (poor)

Tabel 2. Eksternal Faktor Strategi (EFAS)

\begin{tabular}{|c|c|c|c|}
\hline $\begin{array}{l}\text { Faktor-Faktor } \\
\text { Strategi } \\
\text { Internal }\end{array}$ & Bobot & Rating & $\begin{array}{l}\text { Skor }= \\
\text { Bobot } x \\
\text { Rating }\end{array}$ \\
\hline $\begin{array}{l}\text { a) } \begin{array}{l}\text { Peluang/Op } \\
\text { portunities }\end{array} \\
1 . \quad \ldots \ldots \\
2 . \quad \ldots \ldots \\
\end{array}$ & & & \\
\hline Jumlah (A) & $\mathbf{A}$ & & $\mathbf{A}$ \\
\hline $\begin{array}{ll}\text { b) } & \text { Ancam } \\
\text { an/Threats } \\
\begin{aligned} 1 . & \ldots \ldots \\
2 . & \ldots . . .\end{aligned}\end{array}$ & & & \\
\hline Jumlah (B) & B & & \\
\hline Total & $\begin{array}{c}(A+B= \\
1)\end{array}$ & & $(\mathrm{A}+\mathrm{B})$ \\
\hline
\end{tabular}


Menurut Rangkuti (2015) proses penyusunan perencanaan strategis melalui tiga tahap analisis, yaitu

\section{1) Tahap pengumpulan data}

Tahap ini pada dasarnya tidak hanya sekedar kegiatan pengumpulan data, tetapi juga merupakan suatu kegiatan pengklasifikasikan dan pra analisis. Pada tahap ini data dapat dibedakan menjadi dua, yaitu data eksternal dan data internal.

Data eksternal dapat diperoleh dari lingkungan di luar perusahaan seperti:

- Analisis pasar: golongan/sasaran usaha penjualan

- competitor: pesaing dalam menjual produk

- infrastrukur: memadai atau tersedian saranan transportasi

- Pemasok : dalam memenuhi kebutuhan bahan baku

- Bahan Baku: ketersediaan bahan baku di luar tempat usaha

- Analisis kelompok kepentingan tertentu

Data internal dapat diperoleh dari lingkungan dalam perusahaan itu sendiri, seperti:

- Modal : ketersediaan modal

- Sumber daya Manusia:tenaga kerja, ketersediaan tenaga kerja, kedisiplinan terampil,dan disiplin dalam bekerja

- Bahan baku: tersediaanya bahan baku dalam usaha, atau komoditas bahan baku

- Lokasi: tempat berdirinya usaha

- Produk Sop Buah: menggunakan bahan pengawet atau tidak, inovasi rasa, kualitas produk, penampilan produk.

- Promosi: dilakukan dalam memasarkan produk

- Citra perusaaan : kebersihan, pelayanan.

\section{2) Tahap analisis}

Setelah mengumpulkan semua informasi yang berpengaruh terhadap kelangsungan perusahaan, tahap selanjutnya adalah memanfaatkan semua informasi tersebut dalam model-model kuantitatif perumusan strategi. Sebaliknya kita menggunakan beberapa model sekaligus agar dapat memperoleh analisis yang lebih lengkap dan akurat. Model yang dapat dipergunakan adalah sebagai berikut:

- Matriks Internal dan Eksternal

- Matriks Space
- Matriks Grand Strategi

3) Tahap pengambilan keputusan

Pada tahap ini menilai manakah alternatife indikator indikator yang akan dipilih untuk di jadikan faktor internal dan faktor eksternal.

Perhitungan bobot dan rating dalam analisis SWOT dapat menggunakan kuesioner

Apabila menggunakan kuisioner, sebelumnya perlu diidentifikasi indikator indikator yang ingin ditanyakan dalam kuisioner SWOT. Cara mengidentifikasi indikator SWOT adalah dengan menggunakan kajian literature, wawancara, atau riset eksploratif.

\section{A. Matriks TOWS atau SWOT}

Matriks SWOT dapat menggambarkan secara jelas bagaimana peluang dan ancaman eksternal yang dihadapi dapat disesuaikan dengan kekuatan dan kelemahan yang dimiliki (Rangkuti, 2006). Matriks SWOT adalah ringkasan yang menganalisis kekuatan dan kelemahan internal dalam hubungannya dengan peluang dan ancaman eksternal organisasi yang digunakan utntuk membantu manajer mengembangkan empat tipe strtegi yang merupakan alternatif strategi pemasaran yang dapat di implementasikan oleh perusahaan berdasarkan hasil kombinasi antara faktor eksternal dan internal yang dimiliki oleh perusahaan.

Menurut Fahmi (2013), bahwa berdasarkan nilai peringkat dan pembobotan yang kemudian di kalikan akan diperoleh hasil kombinasi antara beberapa situasi sebagai berikut:

1. Kekuatan dan peluang (S-O) artinya perusahaan menentukan strategi berdasarkan kombinasi kekuatan dan peluang yang bisa manfaatkan kekuatan untuk menggunakan peluang sebaikbaiknya.

2. Kelemahan dan Peluang (W-O) artinya perusahaan harus membuat strategi bagaimana meminimalkan kelamahan yang selalu muncul dalam perusahaan dengan memanfaatkan peluang yang menguntungkan.

3. Kekuatan dan Ancaman (S-T) artinya perusahaan bisa memanfaatkan kekuatan baik dalam hal manajemen, sistem 
pemasaran maupun kemampuan finansial untuk mengatasi ancaman.

4. Kelemahan dan Ancaman (W-T) artinya perusahaan harus meminimalkan kelemahan dan menghindari ancaman.

\section{HASIL DAN PEMBAHASAN}

\section{Gambaran Umum Usaha Sop Buah Ica}

Usaha Sop Buah Ica merupakan salah satu usaha kuliner pengolahan buah buahan segar yang kaya akan berbagai vitamin dan gizi yang ada di dalam buah-buahan. Pemilik Sop Buah Ica ini bernama ibu Hanna Tumewu yang berasal dari jawa. Awal proses produksi Sop Buah ini pada saat perkemahan yang ada di bumi perkemahan GPdI yang pada waktu itu berlangsung di Buha. Pada waktu itu juga banyak yang menyukai Sop Buah karena pada saat itu keadaan cuaca di perkemahan sangat panas sehingga banyak yang membeli sop buah. Setelah selesai berjualan di bumi perkemahan GPdI, Ibu Hanna di tawari tempat untuk membuka usaha pertama kali berjualan Sop Buah di halaman gedung gereja International Christian Assembly (ICA) selama 8 bulan berproduksi. Kemudian pada bulan Maret Tahun 2013 mereka pindah di depan freshmart bahu mall, mereka menyewa tempat yang berukuran $3 \mathrm{~m} \times 7 \mathrm{~m}$ untuk berjualan, di tempat ini proses produksi sudah dalam pekerjaan tiga karyawan. Setelah pindah di tempat baru yaitu di depan Freshmart Bahu Mall, banyak pelanggan-pelanggan baru yang yang datang untuk membeli jajanan sop buah. Di karenakan ada sedikit permasalahan dengan pemilik gedung sewah mereka hanya berjualan disana hanya empat bulan. Banyaknya konsumen maka tempat berjualan pindah di Jln. Piere Tendean di Ruko Bouleveard Square Manado dan saat ini usaha Sop Buah ini sudah ketambahan karyawan menjadi 9 orang karyawan. Ada dari Sop Buah Ica ini "hati yang gembira adalah obat, minum Sop Buah Ica bakalan sehat".

\section{Struktur organisasi}

Usaha "Sop Buah" dikelola dan diawasi secara langsung oleh pemilik usaha. Di karenakan usaha sop buah belum memiliki struktur organisasi yang jelas serta belum menerapkan sistem manajemen secara penuh dan terarah, akan tetapi walaupun belum memiliki struktur organisasi yang jelas semua karyawan yang bekerja di tempat usaha sop buah, bertanggung jawab terhadap tugas masing-masing serta dapat menjalankan kewajibannya dengan baik.

Karyawan Sop Buah Ica saat ini berjumlah 9 orang yang sudah terbagi dalam tugas masingmasing sesuai dengan tugas yang di berikan oleh pemilik usaha yaitu terdiri dari 1 orang yang bertugas di kasir, 1 orang bekerja untuk memasak, 1 orang untuk melakukan memblender buah, 1 orang untuk mencuci piring, 3 orang untuk memotong buah, 1 orang untuk membuat es campur, dan 1 orang yang menjadi penggantar kiriman pesanan. Struktur organisasi sop buah ica adalah sebagai berikut:

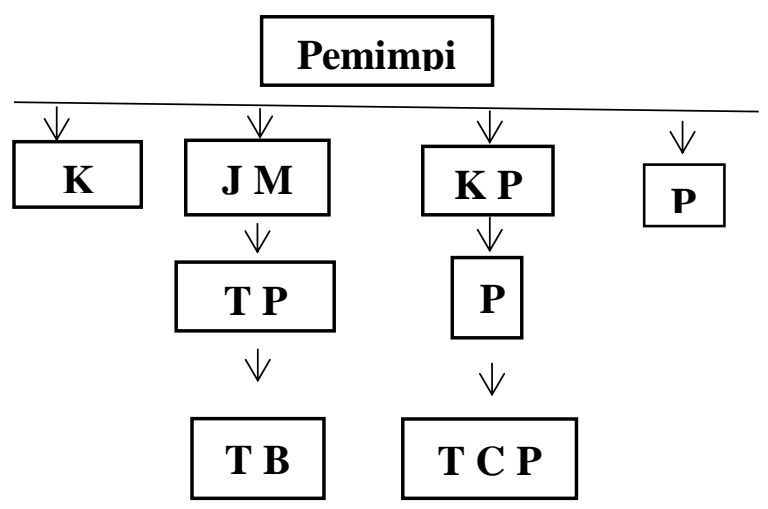

Gambar 3. Struktur organisasi Sop Buah Ica Keterangan uraian pekerjaan :

- Pimpinan: Berfungsi sebagai pembuat keputusan tertinggi, juga mengawasi arus kas yang masuk dan arus kas yang keluar (keuangan secara keseluruhan).

- Kasir: Bertugas untuk melayani pembayaran dari para tamu restoran dan melayani pemesanan melalui telepon.

- Juru Masak: Bertugas untuk memasak pesanan yang masuk dan menyediakan sop buah dan makanan yang terbaik untuk para tamu dan juga memberikan instruksi kepada tukang potong buah.

- Tukang potong: Bertugas memotong buahbuahan, membantu tugas kepala pelayan.

- Tukang Blender: Bertugas memblender buah-buahan, membantu tugas juru masak.

- Kepala Pelayan: Bertugas dan mengawasi pelayan yang melayani para tamu dan memberikan pelayanan yang terbaik, juga menanggapi keluhan dari para tamu.

- Pelayan: Bertugas membantu tugas kepala pelayan. 
- Tukang Cuci Piring dan Gelas: Bertugas mencuci piring dan gelas, membersihkan meja, membantu tugas kepala pelayan.

- Pengantar pesanan: bertugas untuk membawa/mengantar pesanan kepada konsumen yang memesan lewat telepon.

\section{Karateristik Responden}

Karakteristik responden yaitu untuk memberikan gambaran tentang keadaan diri responden. Responden dalam penelitian ini yaitu mencakup, pemilik usaha, karyawan dan konsumen. Responden dari pemilik usaha merupakan pemilik dari usaha Agroindustri Sop Buah, responden karyawan merupakan orang yang bekerja di tempat usaha Sop Buah, dan terakhir responden dari konsumen yang datang dan membeli jajanan Sop Buah. Gambaran keadaan responden meliputi jenis kelamin, dan umur.

\section{Jenis Kelamin}

Jenis kelamin responden dalam penelitian ini adalah pemilik usaha karyawan, dan komsumen yang daatang membeli produk sop buah untuk lebih jelasnya akan disajikan karakteristik responden berdasarkan jenis kelamin yang dapat dilihat pada tabel berikut ini

\section{Tabel 3. Jenis Kelamin Responden}

\begin{tabular}{lccc}
\hline No & Jenis & Jumlah & Persentase \\
kelamin & $\begin{array}{c}\text { Responden } \\
\text { Orang }\end{array}$ & $\%$ \\
\hline
\end{tabular}

\begin{tabular}{lccc}
\hline 1. & $\begin{array}{c}\text { Perempu } \\
\text { an }\end{array}$ & 31 & 79,49 \\
2. & $\begin{array}{c}\text { Laki- } \\
\text { Laki }\end{array}$ & 8 & 20,51 \\
& Jumlah & 39 & 100
\end{tabular}

Sumber: data primer yang diolah 2015

Tabel 3. Menunjukan bahwa karakteristik responden menurut jenis kelamin berjumlah 39 orang responden yang sudah di gabung dengan responden dari pemilik usaha, karyawan, dan konusmen. Dari 39 responden dapat dilihat bahwa jenis jenis kelamin responden perempuan memiliki jumlah yang lebih banyak yaitu 79,49 persen dari pada laki-laki yang hanya berjumlah 20,51 persen.

\section{Umur Reponden}

Deskripsi responden menurut umur menguraikan atau memberikan gambaran mengenai umur dari responden yang menjadi sampel dalam penelitian ini. Oleh karena itulah dalam deskripsi karakteristik responden dari pemilik, karyawan, konsumen menurut umur dapat disajikan deskripsi karakteristik responden menurut umur yaitu sebagai berikut:

Tabel 4. Umur Responden Sop Buah

\begin{tabular}{cccc}
\hline No & Umur & $\begin{array}{c}\text { Jumlah } \\
\text { Responden }\end{array}$ & $\begin{array}{c}\text { Persentase } \\
\%\end{array}$ \\
\hline 1. & $\leq 20$ & 4 & 10.26 \\
2. & $21-30$ & 22 & 56.42 \\
3. & $31-40$ & 9 & 23.08 \\
4. & $41-50$ & 2 & 5.13 \\
5. & $51 \geq$ & 2 & 5.13 \\
\hline & Jumlah & 39 & 100 \\
\hline
\end{tabular}

Sumber: Data primer yang diolah 2015

Tabel 4. menunjukan bahwa usia responden di dominasi oleh umur di antara 21-30 yaitu 56.42 persen dengan jumlah responden dengan umur di atas 21-30, sedangkan persentase yang terendah di dapat pada umur 41-50 dengan 5.13 persen dan di atas 50 dengan persen 5.13 persen berjumlah responden 2 orang.

\section{Identifikasi Faktor-faktor Internal}

A. Modal

Modal adalah segala sesuatu yang dapat digunakan untuk menjalankan suatu usaha atau perusahaan. modal juga di dapat dari dalam perusahan atau yang penambahan dari pihak pemilik perusaan dan juga dari pihak lain. Modal sangat besar mempengaruhi dalam menjalankan suatu usaha atau perusahaan. Dalam menjalankan usaha pemilik usaha sop buah menggunakan modal sendiri atau modal yang digunakan adalah dari tabungan sendiri. Dalam membiayai semua keperluan dalam usaha seperti membeli bahan baku dan bahan penolong, menyewah tempat/ruko untuk berjualan, membayar gaji karyawan dan segala keperluan-keperluan untuk menunjang kelancaran usaha, pemiilik menggunakan modal sendiri. 


\section{B. Ketenaga kerjaan}

Tenaga kerja merupakan penduduk yang berada dalam usia kerja. Tenaga kerja yang dimaksud disini adalah karyawan yang bekerja di tempat usaha:

a) Karyawan cukup terampil

Karyawan yang terampil merupakan seorang karyawan terampil dalam pekerjaanya. Di tempat usaha Sop Buah ini karyawan yang bekerja cukup terampil karena rata-rata menguasai alat-alat yang ada dalam usaha ini.

b) Ketersediaan tenaga kerja lokal

Tenaga kerja lokal yang di maksud di sini adalah karyawan, tersedianya tenaga kerja lokal yang ingin bekerja di tempat usaha ini merupakan hal yang positif karena banyak tenaga kerja lokal yang ingin bekerja di tempat usaha Sop Buah ini.

c) Cukup disiplin dalam bekerja

Kedisiplinan adalah kesadaran dan kesediaan seseorang menaati semua peraturan perusahaan dan norma-norma sosial yang berlaku. Di tempat usaha Sop Buah ini karyawan yang bekerja cukup disiplin, apabila melakukan kesalahan atau melanggar peraturan atau peraturan yang berlaku di dtempat usaha ini akan ditegur secara langsung oleh pemilik usaha.

C. Tersediaanya Bahan Baku Buah-Buahan dan Bahan Penolong dalam Usaha.

Bahan baku buah-buahan dan bahan penolong merupakan bahan yang penting dalam kelancaran proses produksi dalam bidang agroindustri, dimana bahan baku buahbuahan merupakan aspek penting dalam pembuatan Sop Buah. Bahan penolong juga sangat penting karena tersediannya bahan penolong seperti gula, susu, sirup, cup dan sendok plastic dapat mempermudah proses pembuatan dan kelancaran dalam proses pengolahan Sop Buah.

\section{Lokasi/Tempat}

Lokasi adalah suatu tempat di mana perusahaan itu malakukan kegiatan fisik. Salah satu aspek penting dalam berjualan adalah pemilihan lokasi atau tempat usaha berjualan. Dalam pemilihan tempat berjualan usaha sop buah sangat strategis di banding dengan tempat sebelumnya karena tempat yang sekarang sangat strategis karena dekat dengan area kampus dimana sebagian besar konsumen berasal dari mahasisiswa dan dekat juga dengan mall tempat perbelanjaan. Kelebihan lainnya juga lokasi sekarang tempatnya sangat luas atau besar dibanding dengan lokasi sebelumnya.

E. Produk Sop Buah tidak menggunakan pewarna Sop Buah.

Produk adalah barang atau jasa yang dapat diperjual belikan. Produk yang dimaksud disini adalah Sop Buah. Dimana kelebihan dari produk Sop Buah ini adalah tidak menggunakan pewarna dalam Sop Buah, karena warna dari Sop Buah adalah hasil dari buah buahan yang di blender menjadi Sop.

F. Bahan baku buah-buahan yang di gunakan adalah komoditas terbaik.

Bahan baku merupakan salah satu unsur yang paling aktif didalam perusahaan yang secara terus-menerus diperoleh, diubah yang kemudian dijual kembali. Bahan baku yang dimaksud disini adalah buah buahan yang dipakai dalam proses produksi Sop buah. Adapun bahan baku yang digunakan dalam proses produksi Sop Buah adalah komoitas terbaik, karena pemilik usaha mengsortir bahan baku buah buahan yang dipakai terbaik dalam pembuatan Sop Buah, untuk menghasilkan kualitas terbaik dari produk Sop Buah.

\section{G. Inovasi rasa Sop Buah}

Inovasi adalah proses pembaharuan/pemanfaatan/pengembangan dengan menciptakan hal baru yang berbeda dengan sebelumnya. Inovasi juga dapat diartikan penemuan baru dalam teknologi atau kemampuan dalam memperkenalkan temuan baru yang berbeda dari yang telah ada sebelumnya. Berdasarkan penelitian Inovasi rasa sop buah yang terdapat dalam lokasi penelitian adalah setiap jenis-jenis rasa dari sop buah yang di jual terdapat berbagai jenis rasa sop buah yang dijual yakni, sop buah anggur, sop buah strawberry, sop buah mangga, sop buah sirsak, sop buah melon, sop buah nangka, sop buah apel, sop buah alpukat, sop buah semangka, dan sop buah duren, itulah berbagai rasa dari sop buah yang di jual. 
H. Kualitas produk sop buah sangat baik

Produk memiliki arti penting bagi

perusahaan karena tanpa adanya produk, perusahaan tidak akan dapat melakukan apapun dari usahanya. Pembeli akan membeli produk kalau merasa cocok, karena itu produk harus disesuaikan dengan keinginan ataupun kebutuhan pembeli agar pemasaran produk berhasil. Untuk menghasilkan kulitas rasa sop buah yang baik, pemilik menggunakan bahan baku buah buahan yang disortir terlebih dahulu untuk memilih bahan baku buah yang dipakai, supaya menghasilkan kulitas produk yang sangat baik yang diinginkan oleh konsumen.

\section{Harga/Price}

Harga merupakan salah satu penentu keberhasilan suatu perusahaan karena harga menentukan seberapa besar keuntungan yang akan diperoleh perusahaan dari penjualan produknya baik berupa barang maupun jasa. Harga setiap sop buah yang ditawarkan dalam usaha sop buah memiliki harga yang berbeda/bervariasi yang ditawarkan adalah harga sop buah biasa dan harga sop buah banget yang memiliki harga yang berbeda dimana harga sop buah biasa sekitaran Rp 13.000-15.000 dan harga sop buah banget sekitaran Rp 20.000-26.000. harga yang ditawarkan meiliki variasi dalam ukuran, bisa dilihat dalam tabel berikut.

\begin{tabular}{|c|c|c|}
\hline No. & Jenis Sop Buah & $\begin{array}{l}\text { Harga } \\
\text { (Rp) }\end{array}$ \\
\hline 1. & $\begin{array}{l}\text { Sop Buah Banget } \\
\text { (Anggur/Strawberry) }\end{array}$ & 20000 \\
\hline 2. & $\begin{array}{l}\text { Sop buah Banget (Mangga / Sirsak / } \\
\text { Apel/ Alpukat / Melon / Nangka / } \\
\text { Semangka) }\end{array}$ & 18000 \\
\hline 3. & Sop buah Strawberry biasa & 15000 \\
\hline $\begin{array}{l}4 . \\
6 . \\
7 .\end{array}$ & $\begin{array}{l}\text { Sop buah Anggur biasa } \\
\text { Sop buah Mangga biasa } \\
\text { Sop buah Sirsak biasa }\end{array}$ & $\begin{array}{l}15000 \\
13000 \\
13000\end{array}$ \\
\hline $\begin{array}{l}8 . \\
9 . \\
10 .\end{array}$ & $\begin{array}{l}\text { Sop buah Apel biasa } \\
\text { Sop bu ha Alpukat biasa } \\
\text { Sop buah Melon biasa }\end{array}$ & $\begin{array}{l}13000 \\
13000 \\
13000\end{array}$ \\
\hline 11. & Sop buah Nangka biasa & 13000 \\
\hline 12. & Sop buah Semangka biasa & 13000 \\
\hline 13. & Sop buah Duren tok (Banget) & 35000 \\
\hline 14. & Sop buah Duren tok (Biasa) & 25000 \\
\hline 15. & Sop buah Duren Banget & 28000 \\
\hline 16. & Sop buah Duren Biasa & 20000 \\
\hline 17. & Alpukat Duren Banget & 22000 \\
\hline 18. & Alpukat Duren Biasa & 17000 \\
\hline
\end{tabular}

Dapat dilihat dia atas harga dari sop buah yang ditawarkan memiliki harga yang berbeda beda dimana harga Sop buah banget berbeda dengan harga Sop buah biasa.

\section{J. Penampilan poduk sop buah menarik/unik}

Penampilan merupakan gambaran yang jelas tentang prouduk yang di jual. Penampilan disini adalah gambaran dari setiap jenis sop buah yang dihindangkan atau yang di jual, dimana setiap jenis produk sop buah yang di jual mempunyai rasa yang berbeda beda dan dihiasi bermacam-macam buah mejadikan sop buah menarik, enak dipandang dan juga enak dimakan.

\section{K. Kepuasaaan tenaga kerja}

Kepuasan kerja adalah perasaan mendukung atau tidak mendukung yang dialami (pegawai) dalam bekerja dalam suatu usaha. Kepuasan kerja disni adalah :

a) Karyawan puas akan pekerjaanya

Setiap karyawan yang bekerja di tempat usaha Sop Buah merasa puas akan pekerjaan mereka sekarang, karena pekerjaan mereka yang sekarang sesuai di bidang masing-masingnya dan mempunyai hubungan yang baik dengan sesam karyawan.

b) Upah/Gaji sesuai akan hasil kerja

Gaji/Upah (Pay), merupakan faktor pemenuhan kebutuhan hidup pegawai yang dianggap layak atau tidak. Setiap karyawan yang bekerja di usaha ini tidak mengeluh akan upah/gaji mereka, karena sesuai dengan hasil kerja mereka di tempat usaha ini.

c) Pembagian tugas sesuai dengan kemampuan

Tugas yang di berikan oleh pemilik usaha/Manajer sesuai dengan keterampilan dibidangnya masing-masing, karena sesuai dengan kemampuan yang dimiliki oleh setia karyawan yang bekerja di tempat usaha.

\section{Ketersediaan alat penunjang pekerjaan}

Secara umum sarana dan prasarana adalah alat penunjang keberhasilan suatu proses upaya yang dilakukan di dalam pelayanan publik, karena apabila kedua hal ini tidak tersedia maka semua kegiatan yang dilakukan tidak akan dapat 
mencapai hasil yang diharapkan sesuai dengan rencana. Ketersediaanya alat dalam menunjang pekerjaan seperti mixer, pemotong buah, pemeras buah, dan alat alat lain yang sangat penting karena berfungsi sebagai alat pembantu dalam pelaksanaan pekerjaan.

\section{M.Tidak pernah melakukan promosi}

Promosi merupakan salah satu aspek penting karena dalam memasarkan produk dapat meningkatkaan kualitas penjualan untuk meningkatkan kegiatan pemasaran dalam hal memasarkan barang atau jasa dari suatu perusahaan. Dalam memasarkan produk sop buah, pemilik sop buah tidak pernah melakukan promosi dalam bentuk brosur maupun dalam memasarkan dalam media sosial, waluapun tidak pernah melakukan promosi produk sop buah sudah dikenal di kalangan masyarakat karena produk sop buah sudah mempunyai banyak konsumen yang ada dikalangan masyarakarat seperti pegawai maupun mahasiswa.

\section{N. Sumber Daya Manusia (SDM)}

Sumber daya manusia (SDM) adalah salah satu faktor yang sangat penting bahkan tidak dapat dilepaskan dari sebuah organisasi, baik institusi maupun perusahaan. Sumber daya manusia yang dimaksud disini adalah tingkat pendidikan karyawan yang relatife rendah karena rata-rata karayawan yang bekerja hanya berijasahkan sekolah menengah pertama (SMP) dan sebagian juga hanya tamat di sekolah dasar (SD) hanya beberapa karyawan yang menyelesaikan sampai sekolah menengah atas (SMA).

\section{O. Produk Sop Buah tidak bertahan lama}

Produk adalah barang atau jasa yang dapat diperjual belikan. Salah satu kendala dalam memproduksi Sop Buah adalah produk Sop Buah tidak tahan lama. Sop Buah hanya dapat bertahan 2-3 hari saja, dikarenakan bahan baku buah-buahan yang lain tidak dapat bertahan lama setelah diolah menjadi Sop Buah, maka pemilik usaha tidak memproduksi banyak dan hanya memproduski Sop Buah apabila di pesan langsung atau sudah di pesan untuk dikirim ke konsumen yang ingin di antar.

\section{P. Pengemasan}

Pengemasan makanan adalah penyimpanan makanan di dalam kemasan supaya makanan terjaga. Dalam melakukan pengemasan, poduk sop buah hanya membungkus produknya dengan pengemasan biasa seperti gelas plastik. Konsumen menilai pengemasan sop buah kurang menarik karena tidak menampilkan gambar yang menarik atau corak ataupun label yang bisa menampilkan produk sop buah tampak menarik.

\section{Q. Pelayanan/Service}

Pelayanan merupakan kegiatan yang ditawarkan oleh karyawan ke konsumen atau pelanggan dalam, dimana pelayanan mempunyai dampak bagi suatu usaha di karenakan karyawan akan dinilai oleh konsumen baik atau tidaknya karyawan dalam memberikan pelayanan. Dalam lokasi penelitian pelayanan yang diberikan karyawan ke konsumen kurang baik berupa terlambatnya pelayanan. Sebagai contoh lambatnya karyawan dalam membersihkan meja dan lamanya pelayanan dalam membawah pesanan Sop Buah yang dipesan oleh konsumen.

\section{R. Kebersihan}

Kebersihan merupakan salah satu aspek penting dalam usaha makanan. Kebersihan mempunyai dampak yang sangat penting karena konsumen dapat menilai bersih atau tidaknya tempat makanan tersebut. Di tempat usaha sop buah kebersihannya belum terjaga karena banyak konsumen yang mengeluh akan kebersihan di tempat usaha sop buah, seperti banyak sampah seperti tissue yang terletak di meja maupun di lantai, sehingga konsumen akan merasa tidak nyaman makan di tempat.

\section{Hasil Evaluasi Lingkungan Internal}

Setelah dilakukan identifikasi terhadap faktor internal yang berpengaruh terhadap perkembangan usaha Agroindustri "Sop Buah ICA" maka selanjutnya dilakukan evaluasi terhadap faktor faktor tersebut baik dari kekuatan dan kelemahan yang ada dengan menggunakan Analisis Internal Faktor Strategi (IFAS). Berdasarkan evaluasi yang dilakukan diperoleh hasil bobot, rating dan nilai skor yang dapat dilihat pada tabel 10 . 
Berdasarkan tabel 10. Dapat di ketahui bahwa faktor yang menjadi kekuatan utama yang dimiliki usaha Sop Buah Ica adalah tersediannya modal dalam menjalankan usaha sop buah sangat penting dan berpengaruh dalam usaha dengan bobot nilai sebesar 0.08 dan rating 4, sehingga skor yang di dapat 0.32. Selain modal, faktor yang menjadi kekuatan/keunggulan dari usaha Sop Buah ini adalah kualitas dari produk Sop Buah yang baik dengan bobot nilai 0.07 dengan rating 4 dan skor 0.28. faktor yang juga menjadi kekuatan adalah tersediannya bahan baku dan bahan penolong di dalam usaha, lokasi yang strategis, bahan baku buah-buahn komoditas terbaik, inovasi rasa, dan harga produk yang terjangkau dengan bobot 0.06 , rating 3 dan skor 0.18. di susul dengan faktor ketenaga kerjaan (karyawan cukup terampil, ketesediaan tenaga kerja loka, dan cukup disiplin dalam bekerja), Sop buah tidak menggunakan pewarna, penampilan Sop Buah menarik/unik, kepuasaan kerja (Karyawan puas, upah/gaji sesuai, tersediannya alat penunjang pekerjaan), dengan bobot nilai 0.15 , rating 3, dengan skor niali 0.15 . dari hasil analisis IFAS yang di atas jumlah kekuatan yaitu sebesar 2.30.

Kelamahan yang ada di dalam usaha Sop Buah Ica dapat di lihat pada tabel 10. Faktor yang menjadi kelemahan utamanya adalah tidak pernah melakukan promosi, dengan bobot nilai 0.07 , rating 1 dengan skor 0.07 , dan faktor yang kelemahannya yang lain yaitu pelayanan/service kurang memuakan, kebersihan di tempat kurang bersih denga bobot nilai 0.06 , rating 2 dengan skor 0.12 , kemudian faktor sumber daya manusia (tingkat pendidikan relative rendah) dan produk yang tidak tahan dengan bobot 0.04 , rating 2 , dengan skor nilai 0.08 , dan faktor yang terakhir adalah pengemasan kurang menarik, dengan bobot 0.03 , rating 2, skor nilai 0.06 . dan dari hasil analisis IFAS yang di atas jumlah kelemahan yang ada di usaha Sop Buah Ica sebesar 0.53.

\section{Identifikasi Faktor Eksternal}

\section{A. Cuaca panas sangat mempengaruhi permintaan}

Musim panas memang sangat menyiksa ketika seorang di luar ruangan. Pada saat musim panas konsumen akan mencari minuman atau jajanan yang dingin atau es yang dapat menyegarkan tenggorokan. Salah satu yang di cari konsumen adalah Sop Buah. Sop Buah adalah jajanan unik dan inovasi karena di hiasi oleh buah-buahan segar, sehat dan menyegarkan tenggorokan. Pada saat musim panas permintaan akan Sop Buah banyak, karena Sop Buah adalah jajanan unik dan segar karena di hiasi oleh buah buahan yang segar dan kaya akan banyak vitamin dan disajikan dengan dingin.

\section{B. Sasaran usaha}

Target pasar merupakan segmantasi dari tujuan kemana barang atau jasa kita nantinya akan diperkenalkan, dipasarkan, atau dijual. Dalam menjual produk Sop Buah yang menjadi sasaran usaha adalah kalangan menengah ke atas karena dimana kalangan ini sendiri terdiri dari masyarakat biasa dan mahasiswa juga. Semakin banyak orang yang tauh akan produk dari sop buah akan berdampak bagi usaha, dimana sekarang dari kalangan pegawai dari perusahaan menyukai dan tertarik akan sop buah yang enak dan juga harganya yang bersahabat.

\section{Lingkungan aman dalam berjualan}

Lokasi adalah tempat di pilihnya atau berdirinya suatu perusahaan dimana suatu usaha atau aktivitas di lakukan. Pemilihan tempat berdirinya suatu usaha, dapat mempengaruhi suatu usaha. Di samping lokasi yang strategis, lingkungan usaha juga harus mendukung, karena lingkungan yang bagus, bersih dan aman dalam menjalankan usaha bebas dari ancaman pihak pihak tertentu merupakan salah satu faktor penting dalam menjalankan usaha.

D. Tidak adanya pesaing yang menjual produk yang sama

Pesaing merupakan faktor ancaman yang dapat mempengaruhi suatu usaha yang sedang berjalan atau usaha yang baru berjalan. Di area lokasi/tempat berdirinya usaha Sop Buah ini, tidak ada pesaing yang berjualan produk yang sama yaitu Sop Buah, itu adalah nilai plus dari usaha ini, dimana tidak ada pesaing yang berjualan produk yang sama, sehingga sedikit mengecilkan pesaing sesama menjual jajanan dari produk pertanian. 


\section{E. Kesadaran pentingnya buah-buahan}

Buah merupakan produk olahan dari buah buahan yang kaya akan gizi dan vitamin yang penting dalam tubuh manusia. Pentingnya kesadaran konsumen akan buah-buahan bagi kesehatan sangat berpengaruh bagi usaha sop buah, dikarenakan produk yang dijual merupakan olahan dari buah-buahan segar. Semakin sadarnya konsumen akan buah-buah yang kaya akan vitamin bisa berdampak dalam penjualan sop buah, karena konsumen akan mengkonsumsi sop buah yang bahan utamanya adalah buah-buahan yang kaya akan gizi dan vitamin yang baik untuk tubuh.

\section{F. Tersediannya sarana dan prasarana transpotrasi \\ Tersediannya sarana dan prasarana} transportasi sangat penting dan merupakan sarana pendukung bagi perkembangan suatu usaha dalam berinvetasi. Jalan merupakan prasarana yang penting untuk menunjang mobilitas orang, barang dan jasa. Tersediannya sarana prasarana transportasi memudahkan konsumen untuk datang ke tempat usaha Sop Buah, karena lokasi yang sangat strategis dan banyak transportasi mikro yang lalu lalang di jalan boulevard manado sanga memudahkan untuk datang dan membeli produk Sop Buah.

\section{G. Tersediaanya bahan baku buah-buahan dan penolong di pasar}

Dari sisi ketersediaan bahan baku buahbuahan dan bahan penolong banyak, dapat di katakan banyak karena kita bisa jumpa di pasar swalayan dan pasar traditional. Karena itu lancarnya pemilik suaha mencari bahan baku buah-buahan dan bahan penolong karena ketersediaanya banyak di pasar.

\section{H. Cuaca hujan mempengaruhi permintaan}

Cuaca adalah keadaan rata-rata udara pada suatu kawasan yang terjadi dalam waktu relative singkat. Di manado mempunyai dua iklim cuaca, yaitu hujan dan panas. Dalam berjualan produk Sop Buah cuaca hujan mempengaruhi permintaan, apabila cuaca hujan permintaan konsumen akan produk sop buah mengalami penurunan karena konsumen akan lebih beralih mencari minuman yang hangat atupun makanan yang hangat.
I. Harga bahan baku buah buahan tidak stabil

Dalam pengolahan Sop Buah sebagian besar bahan bakunya berasal dari buah buahbuahan. Tidak stabilnya harga bahan baku buah-buahan di pasar maupun pemasok di sebabkan karena bahan baku buah-buahan yang bersifat musiman apabila tidak musim buah contoh: seperti alpukat, anggur, mangga, melon, durian, dapat mengalami kenaikan harga buah di pasar maupun di pemasok buah, dan juga menganggu proses pengolohan karena pemilik akan mengurangi isi dari Sop Buah.

\section{J. Pesaing}

Pesaing adalah perusahaan lain yang menghasilkan barang atau produk yang sama dan menjual barang dan produk yang sama atau mirip dengan produk yang ditawarkan. Dalam lingkungan usaha sop buah, munculnya pesaing yang lain yang menjual jajanan buah buahan sebagai produk utaman menambah persaingan dalam berjulan produk. Walaupun banyaknya pesaing, Sop Buah sudah mempunyai konsumen yang sudah menjadi langganan sehingga tidak banya menganggu akan penjulan Sop Buah.

\section{K. Suplai bahan baku buah-buahan tidak kotinyu}

Produksi kontinyu adalah suatu metode proses produksi di mana proses berlangsung secara terus menerus tanpa terhenti. Dalam membeli bahan baku buah buahan pemilik mengalami masalah, apabila bahan baku buah buahan lain tidak ada di pasar sawalayan atau di pasar traditional maka pemilik usaha akan kekurangan stock bahan baku buah buahan. Walaupun sudah ada pemasok buah-buahan ke pemilik usaha ada juga halangan pemasok dalam memenuhi kebutuhan buah-buahan, halangan yang dimaksud adalah keterlambatan pemasok dalam memenuhi kebutuhan karena pemasok buah-buahan berasal di luar daerah manado dan juga ada di luar pulau Sulawesi. Akibat keterlambatan pemasok buah-buahan dapat mengakibatkan kekurangan stock bahan baku buah-buahan di usaha.

\section{Naiknya biaya sewa ruko}

Mempunyai lokasi usaha yang bagus dan strategis adalah impian bagi setiap orang yang ingin memulai usaha. Salah satu ancaman ke depan yang ada di tempat usaha adalah biaya 
sewah. Lokasi yang sangat strategi juga berpengaruh akan biaya sewa tempat/ruko yang di tempatkan sekarang, karena apabila kedepan biaya sewa ruko naik, akan berpengaruh terhadap pendapatan usaha.

\section{Hasil Evaluasi Lingkungan Eksternal}

Setelah dilakukan identifikasi terhadap faktor eksternal yang berpengaruh terhadap perkembangan usaha Agroindustri "Sop Buah ICA" maka selanjutnya dilakukan evaluasi terhadap faktor faktor tersebut baik dari peluang dan ancaman yang ada dengan menggunakan Analisis Eksternal Faktor Strategi (EFAS). Berdasarkan evaluasi yang dilakukan diperoleh hasil bobot, rating dan nilai skor yang dapat dilihat pada tabel 11 .

Berdasarkan tabel 11. Di ketahui bahwa faktor yang menjadi peluang utama dari usaha Sop buah ini adalah tidak ada usaha lain yang menjual produk yang sama, tersediannya sarana transportasi, dan tersediaanya bahan baku buah dan penolong di pasar, dengan bobot nilai 0.1, rating 4, dan skor 0.4. dan faktor-faktor yang menjadi peluang usaha Sop buah ini antara lain cuaca panas sangat mempengaruhi permintaan Sop buah dengan bobot, 0.09 , rating 4 dengan skor 0.36, lokasi aman dalam mendirikan usaha dengan bobot nilai 0.08 , rating 3 , dengan skor 0.24 sasaran usaha, dan kesadaran pentingnya buah buahan dalam kesehatan bobot nilai 0.07, rating 3 dan skor 0.21. dari hasil analisis EFAS di atas jumlah seluruh peluangnya adalah 2.22.

Faktor ancaman dapat mempengaruhi suatu usaha yang sedang berjalan, dapat dilihat pada tabel 11. Yang menjadi ancaman utama usaha Sop buah ini adalah naiknya biaya sewa ruko dengan bobot nilai 0.1 , rating 1 , dengan skor 0.1. selain itu faktor-faktor yang menjadi ancaman yang lain antara lain cuaca hujan sangat mempengaruhi permintaan dengan bobot 0.09 , rating 1 , skor 0.09 , faktor kondisi harga bahan baku buah, suplai bahan baku tidak kontinyu dengan bobot 0.07 , rating 2 , skor nilai 0.14 , dan fakor yang terakhir, adanya persaingan dengan produk lain yang berbahan baku buah-buah segar cukup banyak dengan bobot, 0.06, rating 2, dengan skor 0.12. dari hasil analisis EFAS di atas jumlah seluruh ancaman adalah 0.59 .

Dari hasil analisis internal faktor strategi (IFAS) dan eksternal faktor strategi (EFAS) diatas, menghasilkan rankaian skor sebagai berikut:

1. Kekuatan (Strengths) $\quad=2,30$

2. Kelemahann (Weakness) $=0.53$

3. Peluang(Opportunities) $=2,22$

4. Ancaman (Threats) $=0,59$

Hasil dari analisis pada diagram SWOT diperoleh koordinat 1,77:1,63 yang koordinatnya ini berada pada kuadran I yaitu strategi agresif. Pada posisi ini merupakan situasi yang sangat menguntungkan perusahaan karena perusahaan memiliki peluang dan kekuatan yang sangat besar sehingga perusahaan dapat memanfaatkan peluang yang ada. Strategi ini menunjukan situasi yang sangat menguntungkan. Pengembangan usaha Sop Buah ICA di Boulevard manado memiliki kekuatan dan peluang yang sifatnya saling mendukung, yaitu dengan cara menggunakan semua faktor kekuatan dengan memaksimalkan peluang yang sebaik baiknya.

\section{Matriks TOWS atau SWOT}

Matriks SWOT dapat menggambarkan secara jelas bagaimana peluang dan ancaman eksternal yang dihadapi dapat disesuaikan dengan kekuatan dan kelemahan yang dimiliki (Rangkuti, 2006). Matriks SWOT adalah ringkasan yang menganalisis kekuatan dan kelemahan internal dalam hubungannya dengan peluang dan ancaman eksternal organisasi yang digunakan utntuk membantu manajer mengembangkan empat tipe strtegi yang merupakan alternatif strategi pemasaran yang dapat diimplementasikan oleh perusahaan berdasarkan hasil kombinasi antara faktor eksternal dan internal yang dimiliki oleh perusahaan. Adapun analisis dengan pendekatan matriks SWOT ini, dapa dilihat pada tabel 12.

Berdasarkan tabel 12, di atas diperoleh beberapa strategi yang bisa dilakukan dalam pengembangan usaha Agroindustri Sop buah Ica di Boulevard Manado dalam upaya untuk memaksimalkan kekuatan dan memanfaatkan peluang serta meminimalkan kelemahan dan mengatasi ancaman yang ada adalah sebagai berikut:

1) Kekuatan dan peluang ( $\mathrm{S}-\mathrm{O})$

Strategi ini dibuat berdasarkan kombinasi kekuatan dan peluang yang bisa manfaatkan kekuatan untuk menggunakan peluang sebaik-baiknya, yaitu: 
a. Memanfaatkan modal yang selalu untuk bisa membeli keperluan-keperluan dalam usaha. (s1,s3,s6,o6,o7). Modal merupakan hal yang sangat penting dalam mengembangkan suatu usaha. Modal yang digunakan pemilik usaha Sop Buah adalah milik sendiri atau modal pribadi, sehingga dapat membeli dan memenuhi segala keperluan bahan baku buah-buahan dan penolong di dalam usaha, dan dengan tersediannya sarana transportasi untuk pergi ke pasar traditional dan pasar swalayan, memudahkan pemilik dalam mencari bahan baku buah-buahan dan penolong.

b. Memanfaatkan peluang pasar dengan harga jual produk. (s5,s7,s8,s,9,s10,o1,o5).

Dalam menanggapi tinggihnya permintaan konsumen akan produk sop buah pada saat cuaca panas, merupakan peluang bagi pemilik usaha Sop Buah untuk meningkatkan produksinya, dengan memiliki kualitas produk yang baik dan mempunyai kelebihan yang lain dimana, banyak pilihan rasa, begitu juga dengan harga yang terjangkau, dan memiliki tampilan yang unik dari setiap produk menjadi kelebihan usaha Sop Buah ini. Dan dengan memanfaatkan tren akan pentingnya buah buah-buahan dalam kesehatan dalam sangat berpengaruh dikarenakan produk dari Sop Buah ini merupakan olahan dari buah-buahan yang kaya akan vitamin dan mempunyai gizi yang tinggi yang baik untu kesehatan.

2) Kelemahan dan Peluang (W-O)

Dalam membuat strategi ini perusahaan harus membuat strategi bagaimana meminimalkan kelemahan yang selalu muncul dalam perusahaan dengan memanfaatkan peluang yang menguntungkan.

a. Melakukan promosi produk sop buah ke tempat tempat umum untuk menambah konsumen baru (w1,o1,o2,o5). Kemampuan suatu usaha dalam memasarkan produknya dapat meningkatkan kualitas penjualan dengan memanfaatkan peluang yang ada. Dengan melihat kondisi cuaca yang sedang panas terik dan melihat tren yang sedang berkembang saat ini akan pentingnya buahbuahan dalam kesehatan, pemilik harus berjualan dan mempromosikan produknya ke tempat yang banyak kerumunan orang, karena produk Sop Buah ini cocok akan cuaca panas karena buah-buahan yang segar, kaya akan vitamin dan baik untuk kesehatan, sehingga produk Sop Buah bisa di kenal banyak kalangan dan menambah peminat Sop Buah ini.

b. Meningkatkan kualitas sumber daya manusia yang ada (w2,w5,w6,o2,o7).

Salah satu faktor yang penting dan tidak dapat dilepaskan dalam suatu usaha adalah Sumber Daya Manusia (SDM)/karyawan. Rata-rata karyawan yang bekerja di dalam usaha ini adalah hanya tamatan dari sekolah dasar (SD) saja, sehingga menghambat karyawan dalam penyerapan teknologi dan informasi yang baru dan modern sekarang. Selain teknologi dan informasi, di butuhkan pelatihan pelatihan untuk mengajarkan cara melayani konsumen dengan baik, sehingga konsumen bisa merasa puas akan pelayanan yang di berikan oleh karyawan dan menambah citra positif dari usaha ini. Pelatihan-pelatihan lain yang diberikan oleh pemilik usaha kepada karyawannya antara lain, bagaimana cara memilih buah yang komoditasnya bagus di pakai dalam olahan Sop Buah, tersediaanya bahan baku buah-buahan dipasar traditional dan pasar swalayan memudahkan karyawan mencari buah-buah yang bagus dipakai dalam olahan Sop Buah.

3) Kekuatan dan Ancaman (S-T)

Strategi ini memanfaatkan kekuatan baik dalam hal manajemen, sistem pemasaran maupun kemampuan finansial untuk mengatasi ancaman.

a) Memanfaatkan buah-buah lain yang ada di pasar, untuk keperluan penggolahan sop buah, itu juga bisa membantu karena memberikan warna baru terhadap isi sop buah (s1,s6,s10,t2).

Strategi ini harus dilakukan mengingat modal yang selalu tersedia dalam menjalan usaha menambah hal positif dalam usaha ini. Dalam membeli bahan baku buahbuahan untuk pengolahan sop buah, 
pemilik harus memanfaatkan modal yang selalu tersedia untuk membeli bahan baku buah yang berkualitas untuk dipakai, walaupun harga bahan baku buah-buahan yang tidak stabil dalam pasaran. dari itu pemilik harus mencari alternative lain dimana memanfaatkan buah-buahan yang ada di pasar untuk menambah inovasi rasa dalam Sop Buah.

b) Mencari pemasok lain, selain pemasok yang sudah menjadi langganan (s3,s6,t4).

Dalam hal ini, strategi yang harus ditempuh oleh pemilik usaha adalah berkerja sama dengan pemasok lain. Walaupun sudah ada pemasok yang menjadi langganan, kadang dari pemasok yang menjadi langganan tersebut mendapat hambatan dalam memenuhi kebutuhan buah-buahan dalam usaha. Halangan yang dimaksud antara lain sifat buah-buahan yang musiman sehingga pemasok sulit memenuhi permintaan buah-buahan dalam proses pengolahan Sop Buah. Jadi dari itu pemilik harus mencari pemasok lain untuk bekerjasama dimana pemasok lain bisa memenuhi stock buah-buahan dalam usaha. Walaupun harus mencari pemasok lain untuk memenuhi permintaan akan buahbuahan dalam usaha, pemilik juga harus memberikan syarat akan buah-buahan, dimana syarat yang harus dimiliki oleh pemasok lain, harus mendapatkan buahbuahan komoditas yang sama baik dengan pemasok yang menjadi langganan.

c) Mempertahankan kualitas produk (s7,s8,s9,s10,t3). Adanya persaingan dengan produk lain menambah tantangan bagaimana cara dari pemilik untuk bisa bersaing menanggapi adanya banyak sainggan yang datang mengacam usaha pemilik. Walaupun banyak sainggan yang muncul dan mengacam akan usaha Sop Buah, pemilik harus memutar otak, bagaimana cara untuk bisa bersaing dengan produk olahan lainnya. Dengan menambah inovasi rasa yang baru untuk memberikan cita rasa Sop Buah yang baru yang unik dan mempertahankan kualitas dari Sop Buah yang sudah lama menjadi keunggulan dari usaha ini maka pemilik bisa bersaing dengan usahah lain. Keunggulan lain yang ada dari usaha Sop Buah adalah harga. Selain kualitas Sop Buah yang sudah teruji dan mempunyai banyak pilihan rasa Sop Buah, persaingan harga juga adalah salah satu faktor yang mempengaruhi dan menjadi persilisahan antara pesaing usaha. Harga yang terjangkau dari setiap variasi dan ukuran Sop Buah membuat pemilik Sop Buah bisa bersaing dengan usaha lain dengan persaingan antara harga produk masing masing

4) Kelemahan dan Ancaman (W-T)

Strategi yang harus dilakukan pemilik usaha adalah meminimalkan kelemahan dan menghindari ancaman.

a) Meminimalisir produksi sop buah dalam perubahan cuaca tertentu (w3,t1,).

Dalam perubahan musim yang berubah ubah atau kadang tidak menentu, dari musim panas ke musiman dingin, pemilik harus meminimalisir akan produksinya di karenakan pada saat cuaca dingin minat atau permintaan akan sop buah akan menurun karena pada saat itu konsumen akan mencari makanan yang hangat untu menghangatkan badan. maka dari pada itu, dengan cara meminamilisir produksi maka menekan kerugian produk Sop Buah. Selain dari cuaca hujan mempengaruhi permintaan dan minat akan Sop Buah, produk Sop Buah yang tidak tahan lama juga menjadi kelemahan yang harus dihindari sehingga tidak menjadi kerugian dalam memproduksi Sop Buah. Salah satu cara menekan kerugian tersebut adalah dengan tidak memproduksi masal, karena pada saat itu juga dengan tidak memproduksi masal maka menekan kerugaian di dalam usaha. 
Tabel 6. Tabel Analisis Internal Faktor Strategi (IFAS)

\begin{tabular}{|c|c|c|c|}
\hline Uraian & Bobot & Rating & Skor \\
\hline Strengths & & & \\
\hline 1. Ketersediaan modal dalam menjalankan usaha & 0,08 & 4 & 0.32 \\
\hline \multicolumn{4}{|l|}{ 2. Tenaga kerja } \\
\hline $\begin{array}{l}\text { a. Karyawan cukup terampil dalam bekerja } \\
\text { b. Ketersediaan tenaga kerja lokal } \\
\text { c. Cukup disiplin dalam bekerja }\end{array}$ & 0,05 & 3 & 0.15 \\
\hline $\begin{array}{l}\text { 3. Cukup tersedia bahan baku buah dan bahan penolong dalam } \\
\text { usaha }\end{array}$ & 0,07 & 3 & 0.18 \\
\hline 4. Lokasi/ tempat yang strategis & 0,06 & 3 & 0.18 \\
\hline 5. Keamanan terhadap pengawet dan pewarna produk & 0,05 & 4 & 0.20 \\
\hline $\begin{array}{l}\text { 6. Kualitas bahan baku buah yang digunakan komoditas cukup } \\
\text { baik }\end{array}$ & 0,06 & 3 & 0.18 \\
\hline 7. Inovasi rasa dari setiap jenis sop buah unik & 0,06 & 3 & 0.18 \\
\hline 8. Kualitas dari setiap produk sop buah sangat baik & 0,07 & 4 & 0.28 \\
\hline 9. Harga produk sop buah terjangkau & 0,05 & 3 & 0.18 \\
\hline 10. Penampilan produk dari setiap sop buah menarik/unik & 0,05 & 3 & 0.15 \\
\hline 11. Kepuasaa tenaga kerja & & & \\
\hline $\begin{array}{l}\text { a. Karyawan puas akan pekerjaan sekarang } \\
\text { b. Upah/gaji sesuai akan hasil kerja } \\
\text { c. Pembagian tugas sesuai dengan kemampuan }\end{array}$ & 0,05 & 3 & 0.15 \\
\hline 12. Tersediaanya akan alat alat dalam penunjang pekerjaan & 0,05 & 3 & 0.15 \\
\hline \multicolumn{3}{|l|}{ Jumlah } & 2.30 \\
\hline $\begin{array}{l}\text { Uraian } \\
\text { Kelemahan }\end{array}$ & Bobot & Rating & Skor \\
\hline 1. Tidak pernah melakukan promosi & 0,07 & 1 & 0.07 \\
\hline $\begin{array}{l}\text { 2. Sumber Daya Manusia (Tingkat pendidikan karyawan relatif } \\
\text { rendah) }\end{array}$ & 0,04 & 2 & 0.08 \\
\hline 3. Produk sop buah tidak tahan lama & 0,04 & 2 & 0.08 \\
\hline 4. Pengemasan produk dari sop buah kurang menarik & 0,03 & 2 & 0.06 \\
\hline $\begin{array}{l}\text { 5. Pelayanan/service yang di berikan oleh karyawan kurang } \\
\text { memuaskan }\end{array}$ & 0,06 & 2 & 0.12 \\
\hline 6. Kebersihan di tempat sop buah kurang bersih & 0,06 & 2 & 0.12 \\
\hline ( & 1.00 & & 0.53 \\
\hline
\end{tabular}

Sumber: Data Diolah 2016

Tabel 7. Analisis Eksternal Faktor Strategi (EFAS)

\begin{tabular}{|c|c|c|c|}
\hline Uraian & Bobot & Rating & Skor \\
\hline \multicolumn{4}{|l|}{ Peluang } \\
\hline 1. Cuaca panas sangat mempengaruhi permintaan konsumen & 0,09 & 4 & 0.36 \\
\hline 2. Golongan masyarakat/sasaran usaha, kalangan menengah ke atas & 0,07 & 3 & 0.21 \\
\hline 3. Lingkungan aman dan kondusif dalam mendirikan usaha & 0,08 & 3 & 0.24 \\
\hline 4. Tidak ada usaha lain dari pesaing yang menjual produk yang sama. & 0,1 & 4 & 0.4 \\
\hline 5. Kesadaran pentingnya buah-buahan akan kesehatan & 0,07 & 3 & 0.21 \\
\hline 6. Tersediannya sarana transportasi/infrastruktur & 0,1 & 4 & 0.4 \\
\hline \multicolumn{4}{|l|}{$\begin{array}{l}\text { 7. Tersediannya bahan baku buah dan bahan penolong di pasar } \\
\text { traditional dan di pasar swalayan }\end{array}$} \\
\hline \multicolumn{3}{|l|}{ Jumlah } & 2.22 \\
\hline Uraian & Bobot & Rating & Skor \\
\hline \multicolumn{4}{|l|}{ Ancaman } \\
\hline 1. Cuaca hujan sangat mempengaruhi permintaan konsumen & 0,09 & 1 & 0.09 \\
\hline 2. Kondisi Harga bahan baku dan tidak stabil di dalam pasaran & 0,07 & 2 & 0.14 \\
\hline $\begin{array}{l}\text { 3. Adanya persaingan dengan produk lain yang berbahan baku buah } \\
\text { buah segar, cukup banyak }\end{array}$ & 0,06 & 2 & 0.12 \\
\hline 4. Suplai bahan baku buah buahan tidak kontinyu dari pemasok & 0,07 & 2 & 0.14 \\
\hline 5. Naiknya biaya sewa ruko berpengaruh terhadap pendapatan & 0,1 & 1 & 0.1 \\
\hline Jumlah & 1.00 & & 0.59 \\
\hline
\end{tabular}

Sumber: Data Diolah 2016 
Tabel 8. Matriks Analisis SWOT (Strengths, Weakness, Opportunities, Threats)

\begin{tabular}{|c|c|c|}
\hline & \begin{tabular}{|l|}
$\begin{array}{l}\text { Strengths (S) } \\
\text { (kekuatan) }\end{array}$ \\
\end{tabular} & $\begin{array}{l}\text { Weakness(W) } \\
\text { (Kelamahan) }\end{array}$ \\
\hline & $\begin{array}{l}\text { 1. Modal usaha tersedia dalam menjalankan usaha } \\
\text { 2. Ketenaga kerjaan } \\
\text { a) Karyawan cukup terampil } \\
\text { b) Ketersediaan tenaga lokal } \\
\text { c) Cukup disiplin dalam bekerja } \\
\text { 3. Tersedia bahan baku buah-buahan dan penolong } \\
\text { dalam usaha } \\
\text { 4. Lokasi/Tempat yang strategis } \\
\text { 5. Produk sop buah tidak menggunakan pewarna sop } \\
\text { 6. Bahan yang digunakan dalam sop buah adalah } \\
\text { komoditas terbaik } \\
\text { 7. Inovasi rasa sop buah unik } \\
\text { 8. Kualitas dari setiap produk Sop buah sangat baik } \\
\text { 9. Harga produk Sop buah terjangkau } \\
\text { 10. Penampilan dari setiap produk Sop buah } \\
\text { menarik/unik } \\
\text { 11. Kepuasan tenaga keja } \\
\text { a) Karyawan puas akan pekerjaan sekarang } \\
\text { b) Upah/gaji sesuai hasil kerja } \\
\text { c) Pembagian tugas sesuai dengan kemampuan } \\
\text { 12. Tersedianya akan alat-alat penunjang pekerjaaan }\end{array}$ & $\begin{array}{l}\text { 1. Tidak pernah melakukan } \\
\text { promosi } \\
\text { 2. Sumber Daya Manusia } \\
\text { SDM (tingkat pendidikan } \\
\text { karyawan relative rendah } \\
\text { 3. Produk Sop buah tidak } \\
\text { tahan lama } \\
\text { 4. Pengemasan produk dari } \\
\text { sop buah kurang } \\
\text { menarik } \\
\text { 5. Pelayanan/service yang } \\
\text { diberikan olah karyawan } \\
\text { kurang menarik } \\
\text { Kebersihan di tempat } \\
\text { Sop buah kurang bersih }\end{array}$ \\
\hline $\begin{array}{l}\text { Opportunities }(\mathrm{O}) \\
\text { (Peluang) }\end{array}$ & Strategi untuk $(\mathrm{S}, \mathrm{O})$ & Strategi untuk $(\mathrm{W}, \mathrm{O})$ \\
\hline 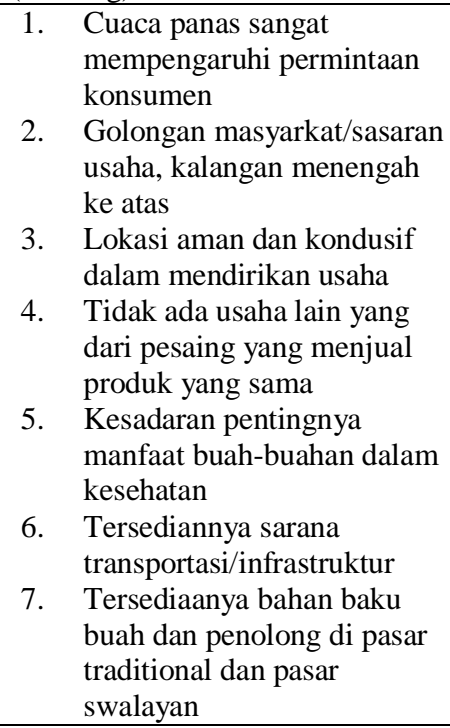 & $\begin{array}{l}\text { 1. Memanfaatkan modal yang selalu tersedia untuk } \\
\text { bisa membeli keperluan-keperluan dalam usaha } \\
\text { Sop Buah. (s1,s3,s6,o6,o7). } \\
\text { 2. Memanfaatkan peluang pasar dengan harga jual } \\
\text { produk. (s4,s5,s7,s8,s,9,s10,o1,o5) }\end{array}$ & 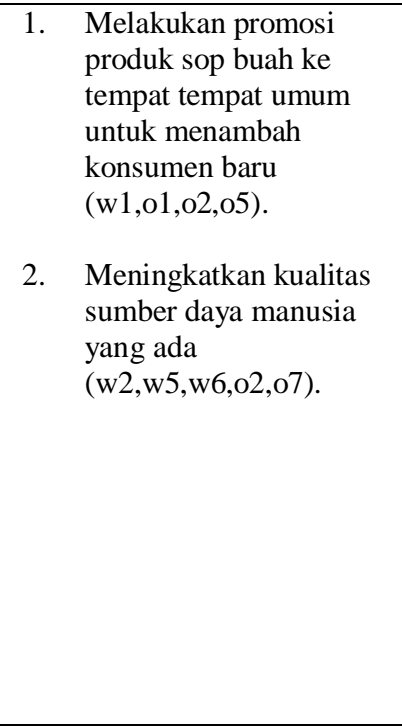 \\
\hline $\begin{array}{l}\text { Threats }(\mathrm{T}) \\
\text { (Ancaman) }\end{array}$ & Strategi untuk $(\mathrm{S}, \mathrm{T})$ & Strategi untuk $(\mathrm{W}, \mathrm{T})$ \\
\hline 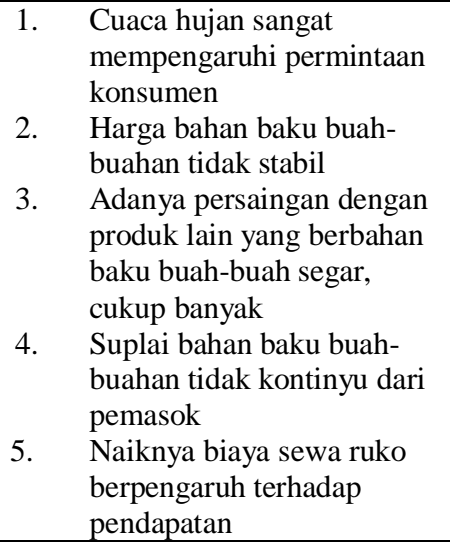 & $\begin{array}{l}\text { 1. Memanfaatkan buah-buah lain yang ada di pasar, } \\
\text { untuk keperluan penggolahan sop buah, itu juga bisa } \\
\text { membantu karena memberikan warna baru terhadap } \\
\text { isi sop buah (s1,s6,s10,t2). } \\
\text { 2. Mencari pemasok lain, selain pemasok yang sudah } \\
\text { menjadi langganan }(\mathrm{s} 3, \mathrm{~s} 6, \mathrm{t} 2, \mathrm{t} 4) \text {. } \\
\text { 3. Mempertahankan kualitas produk (s7,s8,s9,s10,t3) }\end{array}$ & $\begin{array}{l}\text { 1. Meminimalisir produksi } \\
\text { sop buah dalam perubahan } \\
\text { cuaca tertentu }(\mathrm{w} 3, \mathrm{t} 1, \mathrm{t} 2) \text {. }\end{array}$ \\
\hline
\end{tabular}

Sumber: Data Diolah 2016 


\section{KESIMPULAN DAN SARAN}

\section{Kesimpulan}

Berdasarkan penelitian yang telah dilakukan, maka dapat disimpulkan bahwa sebagai berikut:

1. Faktor internal meliputi:

a) Kekuatan: ketersediaan modal, ketenaga kerjaan (Karyawan cukup terampil, ketersediaann tenaga lokal, cukup disiplin dalam bekerja), tersedianya bahan baku buah dan bahan penolong

b) dalam usaha, lokasi/tempat yang strategis, keamanan produk terhadap pengawet dan pewarna, kualitas bahan baku yang digunakan adalah komoditas terbaik, inovasi rasa dari setiap jenis sop buah unik, kualitas dari setiap sop buah adalah baik, harga produk sop buah terjangkau, penampilan dari setiap produk sop buah ica menarik/unik, kepuasan tenaga kerja (karyawan puas akan pekerjaannya, upah/gaji sesuai akan hasil kerja, pembagian tugas sesuai dengan kemampuan), tersedianya alat penunjang pekerjaan.

c) Kelemahan: tidak pernah melakukan promosi, sumber daya manusia (tingkat pendidikan karyawan relatif rendah), produk sop buah tidak tahan lama, pengemasan produk yang kurang menarik, pelayanan karyawan kurang memuaskan, tempat usaha yang kurang bersih.

2. Faktor eksternal:

a) Peluang: cuaca panas sangat mempengaruhi permintaan, golongan masyarakat/sasaran usaha, lingkungan aman dalam mendirkan usaha, tidak ada pesaing yang menjual produk yang sama, kesadaran masyarakat akan pentingnya buah buahan akan kesehatan, tersedia sarana sarana transportasi/infrastruktur, tersedianya bahan buah buahan dan bahan penolong dalam di pasar swalayan atau di pasar traditional.

b) Ancaman : cuaca hujan mempengaruhi permintaan, kondisi harga bahan baku tidak stabil dalam pasaran, adanya persaingan dengan produk lain, suplai bahan baku buah buahan tidak kontinyu dari pemasok, naiknya biaya sewah ruko.

3. Berdasarkan analisis diagram SWOT maka posisi berada pada kuadran I yaitu strategi agresif. Berarti usaha Sop Buah Ica berada pada posisi yang menguntungkan, sehingga perlu diterapkan strategi strategi yang perlu dilakukan, yaitu memanfaatkan modal yang selalu tersedia dengan membeli keperluan dalam usaha sop buah, memanfaatkan peluang pasar dengan harga jual produk, melakukan promosi produk Sop Buah ke tempat umum unutk menambah konsumen baru, meningkatkan sumber daya manusia SDM, memanfaatkan buah-buahan lain yang ada di pasar, untuk keperluan penggolahan Sop Buah, itu juga bisa membantu karena memberikan warna baruterhadap isi Sop buah, mencari pemasok lain, selain pemasok yang sudah menjadi langganan, mempertahankan kualitas produk, meminimalisir produksi Sop buah dalam perubahan cuaca tertentu.

\section{Saran}

Beberapa saran yang dapat diajukan dari hasil pembahasan pada penulisan skripsi ini antara lain:

1) Usaha Sop Buah ICA hendaknya memperluas pangsa pasar atau dengan mendirikan cabang yang baru sehingga produk sop buah ICA bisa mempunyai konsumen yang baru dan bisa dikenal oleh kalangan masyarakat yang luas.

2) Dalam pengemasan atau bungkusan produk sop buah, haruslah mengganti kemasan yang mempunyai corak atau label yang bisa menampilkan produk sop buah tampak menarik bagi konsumen yang membeli dan membawa pulang/take care produk sop buah.

\section{DAFTAR PUSTAKA}

Dinas Pertanian Kota Depok. 2007.Standar Operasional Prosedur Belimbing Dewa Kota Depok. Dinas Pertanian Kota Depok. Depok.

Fahmi, Irham, 2013. Manajemen Strategis Teori dan Aplikasi. Bandung, ALFABETA, cv

Rangkuti, F., 2006. Analisis SWOT: Teknik Membedah Kasus Bisnis. Cetakan keempat belas: Juli 2006. PT Gramedia Pustaka Utama,anggota IKAPI, Jakarta. Agustus 1997.

2015. Analisis SWOT: Teknik Membedah Kasus Bisnis. Cetakan keduapuluh: Juli 2015. PT Gramedia Pustaka Utama,anggota IKAPI, Jakarta. Agustus 1997. 